\title{
ČETRTA ANDRAGOŠKA POLETNA ŠOLA
}

L etošnja Andragoška poletna šola je potekala pod naslovom "Izobraževanje za boljšo zaposljivost ljudi v kraju«. Okrog trideset udeležencev iz vse Slovenije je med 8 . in 12 . junijem sodelovalo v pogovorih, delavnicah, prisluhnilo predavanjem in spremljalo večerni kulturni program v Ajdovščini, mestecu z antičnimi koreninami in prijaznimi ljudmi. Udeležence izobraževalnih dejavnosti kakor tudi goste večernega kulturnega programa, ki ga je pripravila ravnateljica Lavričeve knjižnice Zdenka Lulik Žigon, so že četrtič zapored $\mathrm{z}$ veseljem sprejeli v tej knjižnici.

Poletno šolo je organizirala Katedra za andragogiko Filozofske fakultete iz Ljubljane in vodila prof. dr. Ana Krajnc. Začela se je s pozdravnimi govori župana mesta Kazimirja Bavca, predstavnika ministrstva za šolstvo in šport mag. Jožeta Miklavca in direktorice Zavoda za kulturo in šport Aleksandre Trebižan.

Dnevi so bili razdeljeni v tri dele. Dopoldanski, predavateljsko obarvan del je bil najbolj klasičen, zajemal je teoretična predavanja, popoldan so bile na vrsti razprave, delavnice in delo v skupinah, zvečer pa zabava. Prav večerna srečanja, namenjena neformalnemu druženju med domačini in udeleženci poletne šole, spoznavanju kulturne dejavnosti kraja, so ena od značilnosti te šole. Letos so prisluhnili Tamburaškemu orkestru »Danica«, predstavitvi raziskovalne dejavnosti na ajdovski osnovni šoli Danila Lokarja ter predstavitvi turistične publikacije Vipavska dolina mali slovenski Eden, ki sta jo pripravila dr. Miro Kline in Iris Suban, pospremil pa nastop kvinteta Ventus. Zadnji večer so druženje popestrili člani Univerze za tretje življenjsko obdobje iz Ajdovščine in domači pevski zbor $\gg$ Večernica «.

Tudi v popoldanskem sklopu dejavnosti so imeli pomembno vlogo domačini. Letos so se udeleženci odločali med dvema skupinama, in sicer: »Moja zaposljivost ali kaj bi lahko počel « in »Ugotavljanje lokalnih razvojnih možnosti«. Delo v skupinah je slonelo na neposrednih praktičnih aktivnostih, analizi lokalnih primerov, ugotavljanju potreb na terenu. Učenje je potekalo na osnovi osebnih sti- kov z domačini. Prva skupina se je v popoldanskem delu srečala $\mathrm{z}$ brezposelnimi in z njimi opravila intervjuje, spoznala njihove individualne zgodbe, ogledala si je primere animacije ljudi in pripravila poročilo o zaposljivosti vprašanih. Druga skupina je proučevala lokalne možnosti in razvojne projekte Vipavske doline v obliki študije primera. Učenje je potekalo sredi življenja. Intenzivno enotedensko izobraževanje je prepletalo teorijo s praktičnimi vajami in izkustvi, zato je zahtevalo od vseh sodelujočih precej medsebojne prilagodljivosti, lastne aktivnosti, sprejemljivosti za druge ljudi in za novosti.

Namen poletne šole je bil pokazati na pozitivne vidike brezposelnosti, drugačne možnosti zaposlovanja in na vlogo izobraževalcev odraslih pri nastanku in razvoju lokalnih zaposlitvenih pobud. Vse to se je izražalo v dopoldanskem delu, ko so nastopili:

dr. Konrad Elsdon, profesor z Univerze v Nothinghamu, s predavanjem o izobraževanju $\mathrm{v}$ prostovoljnih organizacijah,

dr. Sonja Kump, s predavanjem o nastajanju in pomenu društev,

mag. Dušana Findeisen, predstavila je solidarnostno gospodarstvo kot svet skupnega učenja in zaposlovanja,

mag. Sabina Jelenc, $z$ delavnico o vzgoji za dejavno državljanstvo in uveljavljanje v poklicu,

dr. Ana Krajnc, predavala je o novih oblikah dela in družbeni integraciji ljudi,

dr. Nena Mijoč, predstavila je načrt za samostojno učenje.

Nastope je zaključila okrogla miza »Kakšno prihodnost si lahko zgradimo «. Dr. Elsdon je poudaril, da za prihodnost odgovarjamo ljudje, zato je pomembno, kakšne aktivnosti izbiramo, kaj bomo storili, in ne le, kaj pričakujemo. Zaposljivosti ljudi ne povečujemo le na ta način, da jim ponujamo nova delovna mesta, ampak predvsem $\mathrm{z}$ razvijanjem njih samih, da si bodo znali poiskati delovno mesto oziroma si ga ustvariti, da bodo sposobni gledati in videti čez okvire naučene rutine. Človek si mora upati, drzniti storiti korak v novo. Človek ni kot reka, ki teče po koritu in se prilagaja, človek je kot voda, ki si korito 


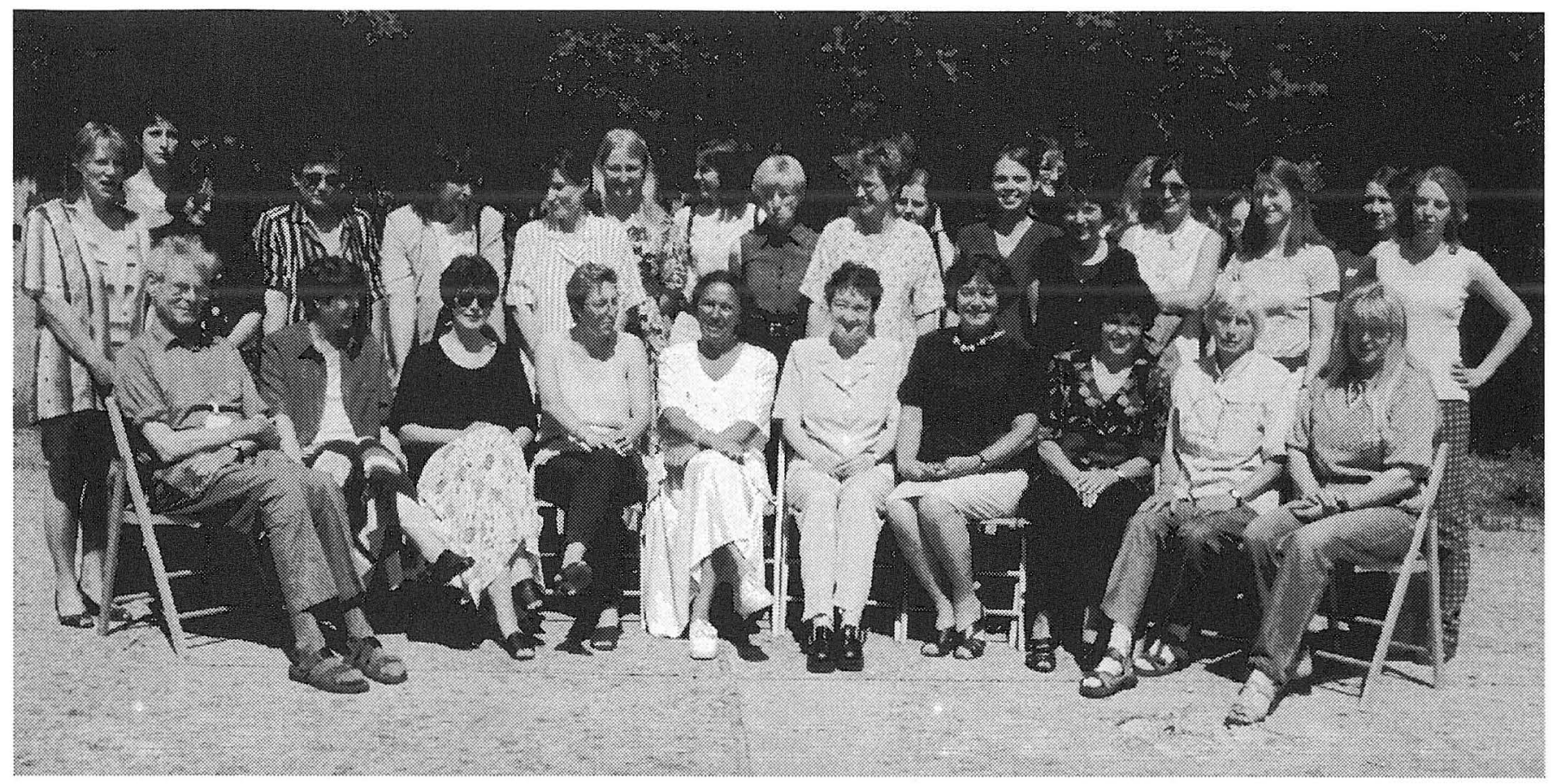

oblikuje. Ljudje morajo imeti možnost izbirati in nositi odgovornost za svojo izbiro. Odgovornost se navezuje na samozavest posameznika, je poudarila dr. Krajnčeva, in na prehajanje iz individualizma $\mathrm{v}$ skupnost.

Sprašujemo se o skupnosti ljudi in o odgovornosti izobraževalcev odraslih pri oblikovanju skupnosti. Naše stoletje označujejo nasilje, tehnološki napredek, hitro naraščanje prebivalstva, politični preobrati ... Politične spremembe ob prehodu dveh blokov $\mathrm{v}$ enega in hkratnem sesuvanju ene od prevladujočih ideologij so še posebej občutile nekdanje države $s$ socialistično in komunistično ureditvijo. Kaj vse to pomeni za naslednje tisočletje? Zanimivo je razmišljanje Evgena Bavčarja, sooblikovalca okrogle mize. Ta slovenski filozof, ki živi v Parizu, ločuje med prihodno- stjo in bodočnostjo. Prihodnost je $\mathrm{v}$ rokah politikov in tehnologij, bodočnost pa je $\mathrm{v}$ rokah ljudi, ki razmišljajo dlje. Med temi so tudi učitelji, izobraževalci odraslih, ki »sanjajo « na daljši čas. Gremo v prihodnost, ampak misliti moramo na bodočnost. Ljudje, ki verjamejo $\mathrm{v}$ bodočnost, delajo za človeka: zoper droge, zoper brezposelnost, zoper prostitucijo ... Današnji človek potrebuje smisel, potrebuje bodočnost, ne le prihodnost.

Ajdovski poletni dnevi so minili v zadovoljstvo organizatorjev in udeležencev. Prijetni vtisi ob srečanjih z novimi ljudmi in tudi $\mathrm{s}$ starimi znanci, ki so bili že četrtič na Andragoški poletni šoli, nova spoznanja in doživetja so razlogi za željo, da bi se prihodnje leto spet srečali v Ajdovščini.

Nives Ličen 